
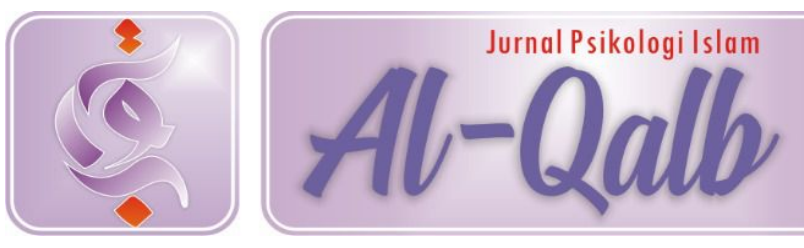

\title{
HUBUNGAN GAYA HIDUP HEDONIS DENGAN PERILAKU KONSUMTIF PADA MAHASISWI
}

Received: $23^{\text {th }}$ September 2018; Revised: $12^{\text {th }}$ October 2018; Accepted: $25^{\text {th }}$ November 2018

\author{
Masnida Khairat \\ UIN Imam Bonjol Padang \\ Email: masnida.khairat@gmail.com \\ Nur 'Aisyiah Yusri \\ UIN Imam Bonjol Padang \\ Email: nuraisyiah@uinib.ac.id \\ Shanty Yuliana \\ UIN Imam Bonjol Padang \\ Email: shantyyuliana13@gmail.com
}

\begin{abstract}
ABSTRAK. Setiap orang memiliki gaya hidup yang berbeda masing-masing. Salah satunya adalah gaya hidup hedonis. Gaya hidup hedonis merupakan pola hidup yang cenderung mencari dan mengejar kesenangan sebagai tujuan hidupnya. Ketika seseorang menerapkan pola hidup seperti ini di dalam dirinya, maka akan menyebabkan seseorang tersebut menunjukkan perilaku konsumtif. Yaitu membelanjakan uangnya untuk suatu hal atau barang secara berlebihan di luar batas kebutuhannya. Tujuan penelitian ini adalah untuk mengetahui kategori dari gaya hidup hedonis pada mahasiswi, untuk mengetahui kategori dari perilaku konsumtif pada mahasiswi, dan untuk mengetahui hubungan gaya hidup hedonis dengan perilaku konsumtif mahasiswi.

Metode yang digunakan dalam penelitian ini adalah metode kuantitatif dengan teknik analisis data yaitu analisis Pearson Correlation. Populasi dalam penelitian ini berjumlah 108 orang dengan sampel sebanyak 84 orang. Penarikan sampel pada penelitian ini adalah simple random sampling. Teknik pengumpulan data yang digunakan dalam penelitian ini adalah skala psikologi, yang berpedoman pada modifikasi skala Likert, yaitu skala gaya hidup hedonis dan skala perilaku konsumtif.

Hasil penelitian menunjukkan bahwa mahasiswi semester IV Prodi Pendidikan Dokter Universitas Baiturrahmah Padang memiliki tingkat gaya hidup hedonis yang tinggi, mahasiswi semester IV Prodi Pendidikan Dokter Universitas Baiturrahmah Padang memiliki tingkat perilaku konsumtif yang tinggi, dan ada hubungan gaya hidup hedonis dengan perilaku konsumtif pada mahasiswi semester IV Prodi Pendidikan Dokter Universitas Baiturrahmah Padang.
\end{abstract}

Kata Kunci: Gaya Hidup, Hedonis, Perilaku Konsumtif.

\section{A. PENDAHULUAN}

Pada era globalisasi ini, dengan terciptanya berbagai teknologi canggih yang dapat mempermudah dan membantu manusia menye-lesaikan urusan-urusannya. Dilihat dari hal yang terkait pemasaran, banyak produk yang ditawarkan kepada masyarakat. Masyarakat bebas memilih dan membeli produk untuk memenuhi kebutuhannya, baik kebutuhan sandang, pangan dan papan. Mulai dari peralatan rumah tangga, fashion, dan kosmetik bagi wanita, dan banyak produk untuk kebutuhan lainnya.

Terlebih lagi bagi masyarakat yang tinggal di perkotaan. Kota adalah tempat untuk membentuk perilaku manusia. Perilaku terbentuk karena ada stimulus yang diterima dan kemudian direspons oleh manusia sesuai dengan makna yang 
didapatkan dari pengetahuan dan pengalaman (Halim, 2008: 13).

Daerah perkotaan yang ditandari dengan banyak pusat-pusat perbelanjaan besar (Mal). Masyarakat di kota akan lebih mementingkan bagaimana dia akan terlihat modern dan mampu mengikuti perkembangan zaman dibandingkan berinteraksi dengan lingkungan sosialnya. Peluang keadaan seperti ini tentu akan membuat masyarakat perkotaan akan lebih berpeluang untuk berbelanja atau berperilaku konsumtif, membeli barangbarang atau produk-produk, baik untuk memenuhi kebutuhan atau hanya pemuasan keinginannya.

Kegiatan konsumtif yang dilakukan oleh masyarakat perkotaan tidak hanya didorong oleh adanya kebutuhan akan fungsi dari barang tersebut saja. Namun, juga didasari oleh keinginan yang sifatnya untuk menjaga gengsi. Hal itu disebabkan oleh banyaknya penawaran dari produkproduk terbaru yang dipromosikan melalui berbagai media seperti media cetak maupun elektronik bahkan melalui penjualan langsung di suatu tempat (pusat perbelanjaan) yang membuat seseorang menjadi mudah terpengaruh untuk mencoba dan membeli barang tersebut walaupun sebenarnya bukan menjadi kebutuhan (Mufidah, 2012).

Mal cenderung menghilangkan interaksi sosial yang terjadi di ruangan publik dan mendorong warganya menjadi konsumtif. Pada perspektif psikologi ini merupakan gejala hilangnya kendali diri (locus of control) seseorang terhadap kesadaran sendiri, mereka akan membeli apa yang sebenarnya tidak mereka butuhkan (Halim, 2008: 124). Perilaku membeli barang atau menghabiskan uang terhadap suatu hal yang tidak menjadi kebutuhan itu disebut dengan perilaku konsumtif. Hal tersebut dilakukan hanya untuk memuaskan hasrat atau keinginannya saja.
Adapun maksud dari perilaku konsumtif menurut menurut Echols dan Shadly (dalam Murbani, 2010: 13) adalah merupakan bentuk kata sifat yang berasal dari "consumer" yang berarti memakai produk, baik barang-barang industri maupun jasa, konsumtif berarti bersifat mengkonsumsi produk atau barang secara berlebihan. Meski dengan kadar yang berbeda-beda, perilaku konsumtif terjadi pada hampir semua golongan di kalangan masyarakat, mulai dari anak-anak, remaja sampai dewasa, mereka semua tidak luput dari hal tersebut. Salah satunya adalah kalangan mahasiswi.

Perilaku konsumtif lebih dominan di kalangan mahasiswi. Karena biasanya perilaku konsumtif ini lebih banyak dilakukan oleh remaja putri dari pada remaja putra. Seperti yang dikatakan oleh Kotgen \& Specht (dalam Ermawati, E., \& Indriyati, 2011) bahwa remaja putri membelanjakan uangnya 2 kali lebih banyak dari pada remaja putra. Lebih lanjut Ningsih dan Bawono (2016) remaja putri juga akan lebih memikirkan bagaimana untuk tampil cantik dan menarik. Sehingga demi menjadi cantik dan menarik, para remaja putri rela menghabiskan uangnya untuk membeli atribut yang mahal atau bermerek, seperti sepatu, tas, pakaian, dan sebagainya yang dapat menunjang penampilannya.

Keramaian yang tercipta di daerah perkotaan tentu tidak akan lepas dari keberadaan para mahasiswa. Baik yang berasal dari luar daerah maupun yang memang penduduk asli perkotaan. Mahasiswa membuat kota menjadi lebih ramai. Sehingga biasanya mahasiswa (remaja) menjadi salah satu target pemasaran yang dituju oleh suatu produk yang dikeluarkan sebuah perusahaan. Ditambah lagi dikarenakan oleh sifat-sifat seorang remaja itu yang labil dan mudah dipengaruhi oleh lingkungannya, gampang terbujuk oleh rayuan iklan yang dibuat, 
cenderung boros, dan tidak realistis (Fitriani, \& Romas, 2014).

Kebutuhan mahasiswa terdiri dari alat tulis kerja, buku paket kuliah, transportasi dari rumah ke kampus dan sebaliknya serta alat penunjang lain yang menjadi kebutuhan perkuliahan, untuk memenuhi kebutuhan tersebut tentu ada pengeluaran yang dilakukan. Pemenuhan kebutuhan memang sangat penting untuk mengantarkan individu pada kehidupan yang selaras dengan lingkungan. Pada setiap orang khususnya mahasiswa, akan melakukan kegiatan konsumsi dan suka terhadap hal-hal yang berbau konsumtif seperti suka berbelanja (Wahidah, 2013: 2).

Kehidupan sering dikaitkan dengan yang namanya gaya hidup. Gaya hidup bisa diekspresikan melalui apa yang dikenakan seseorang, apa yang mereka konsumsi, dan bagaimana cara mereka bersikap atau berperilaku ketika di hadapan orang lain. Mengarah kepada bagaimana seseorang menggunakan uang dan waktunya.

Hawkins (dalam Hasibuan, 2010: 15) mengatakan bahwa gaya hidup seseorang mempengaruhi kebutuhan, keinginan serta perilakunya termasuk perilaku membeli. Gaya hidup juga sering kali dijadikan motivasi dasar dan pedoman dalam memilih sesuatu. Sedangkan menurut Gidden (dalam Arbaini, 2017) mengatakan bahwa gaya hidup merupakan konsep refleksi seperti ketika ada pertanyaan "bagaimana saya hidup?", "siapa saya?", harus di jawab dalam keputusan dari hari ke hari tentang bagaimana perilaku, apa yang dipakai dan apa yang dimakan dan menempatkan dengan cara lain, dalam tatanan post tradisional menjadi sebuah proyek refleksi. Gaya hidup adalah refleksi pola konsumsi pilihan individu tentang bagaimana individu tersebut menghabiskan waktu dan uang.

Perihal gaya hidup, seorang mahasiswa tentu juga memiliki suatu gaya hidup yang dijalaninya. Kalau dilihat dari pernyataan Monks, Knoers, dan Haditono mengenai pembagian fase remaja berdasarkan usianya, mahasiswa mungkin masih bisa dikategorikan sebagai seorang remaja, yaitu termasuk ke fase remaja akhir, yang usianya berkisar antara delapan belas sampai dua puluh satu tahun (Mar'at, 2012: 190).

Remaja mengalami perubahan dalam lingkungan seperti halnya sikap orang tua, saudara, masyarakat umum, maupun teman sebaya. Perubahan di dalam maupun di luar diri remaja itu membuat kebutuhan sosial dan kebutuhan psikologisnya meningkat. Untuk memenuhi kebutuhan tersebut remaja memperluas lingkungan sosialnya di luar keluarga seperti lingkungan teman sebaya. Masa remaja juga merupakan masa seseorang akan berusaha mencari jati dirinya dengan berbagai cara yang dilakukannya.

Hurlock (dalam Murbani, 2010: 5) menyatakan salah satu ciri masa remaja adalah masa yang tidak realistik. Pada masa ini, umumnya remaja memandang kehidupan sesuai dengan sudut pandangnya sendiri yang belum tentu sesuai dengan pandangan orang lain dan juga dengan kenyataan. Selain itu, remaja memandang segala sesuatunya bergantung pada emosinya. Sedangkan emosi remaja yang pada umumnya belum stabil sehingga membuat mereka kurang bersikap bijaksana ketika dihadapkan pada hal-hal yang berhubungan dengan peran mereka sebagai konsumen.

Gaya hidup mal remaja metropolitan telah membuat mereka menjadi generasi "anak nongkrong" yang sering berkeliaran di dalam mal. Hal ini tentu tidak terlepas dari pengaruh globalisasi, baik melalui media cetak maupun elektronik yang menampilkan gaya hidup dunia barat menjadi sebuah gaya hidup global dengan sebuah pesan bahwa jika mereka tidak melakukan apa yang dilakukan oleh anakanak seusia mereka di belahan bumi yang lain itu, maka mereka akan ketinggalan 
zaman alias "jadul" atau jaman dulu (Halim, 2008: 137).

Gaya hidup yang dimaksud disini adalah gaya hidup hedonis, yaitu gaya hidup yang cenderung mencari atau menjadikan kesenangan atau kenikmatan menjadi tujuan dalam hidupnya dan menghindari hal-hal yang menyakitkan. Menghabiskan banyak waktu di luar rumah, menganggap bahwa sumber kebahagiaan adalah mencari kesenangan dan kenikmatan.

Para remaja berkeliaran di mal dengan berbagai kegiatan yang dilakukan, seperti berbelanja barang atau produk yang menunjang penampilan misalnya tas, baju, sepatu, menonton film terbaru di bioskop atau bisa jadi nongkrong di cafe. Menghabiskan waktu dan uang hanya untuk kesenangannya semata tanpa memikirkan hal itu menjadi kebutuhannya atau tidak.

Berdasarkan pengamatan yang telah penulis lakukan di kampus Universitas Baiturrahmah kota Padang khususnya Program Studi Pendidikan Dokter, kebanyakan mahasiswanya pergi ke kampus dengan menggunakan mobil. Area parkirnya lebih banyak dipenuhi oleh mobil dibandingkan oleh sepeda motor. Dengan begitu dapat diambil dipahami bahwa mahasiswa yang mengambil Program Studi Pendidikan Dokter Universitas Baiturrahmah berasal dari keluarga yang tingkat ekonominya menengah ke atas. Jika dilihat dari barangbarang atau atribut penunjang penampilan yang digunakan mahasiswinya, pada umumnya terlihat barang-barang bermerek dan berkualitas yang sudah tentu harganya dikategorikan mahal berdasarkan kantong seorang mahasiswi (Observasi, 16 April 2018, Pukul 14:30 WIB).

Asumsi tersebut diperkuat oleh pernyataan Wakil Dekan II Fakultas Kedokteran Universitas Baiturrahmah bahwa uang masuk awal untuk masuk Program Studi Pendidikan Dokter adalah dua ratus lima puluh juta rupiah dan uang tiap semesternya dua puluh lima juta rupiah (Wawancara, 16 April 2018, Pukul 15:20 WIB).

Jadi, dari keterangan biaya kuliahnya sudah bisa disimpulkan bahwa yang mengambil Program Studi Pendidikan Dokter di Universitas Baiturrahmah adalah anak yang berasal dari keluarga yang mampu atau kelas atas. Dengan keadaan ekonomi yang seperti itu, akan lebih cenderung menimbulkan perilaku konsumtif karena tidak akan lagi memikirkan soal harga dalam membeli sesuatu atau mempertimbangkan uang yang akan keluar. Membeli apa yang diinginkan, karena memang mampu berdasarkan ekomoni, bukan karena dipaksakan (berhutang-hutang). Itulah alasan mengapa penulis memilih Prodi Pendidikan Dokter Universitas Baiturrahmah sebagai tempat penelitian.

Kemudian untuk memperkuat lagi data awal penelitian ini, penulis melakukan wawancara juga dengan dua orang mahasiswi semester IV Program Studi Pendidikan Dokter Universitas Baiturrahmah, yaitu dengan mahasiswi yang berinisial $\mathrm{E}$ dan $\mathrm{P}$, dari wawancara tersebut dapat dipahami bahwa narasumber memiliki hobby dan memanfaatkan waktu luang dengan berjalan keluar rumah, seperti wisata kuliner, menonton di bioskop, atau shopping. Oleh kerena itu, dengan menjalankan gaya hidup yang seperti itu akan cenderung berusaha mendapatkan apa yang diinginkannya, ketika mampu untuk mendapatkannya kenapa tidak, dan akan merasa tidak senang jika belum mendapatkan apa yang diinginkan itu. Bahkan yang diinginkan itu bukan merupakan suatu kebutuhan pada saat itu (Wawancara, 16 April 2018, Pukul 15:00 WIB dan 14 Mei 2018, Pukul 14:29 WIB).

Oleh karena itu, dapat digambarkan bahwa gaya hidup dapat mempengaruhi seseorang untuk berperilaku konsumtif. 
Mahasiswi yang memiliki gaya hidup hedonis akan cenderung berperilaku konsumtif dalam menggunakan uang yang dimilikinya. Dengan demikian, hipotesis dalam penelitian ini adalah terdapat hubungan gaya hidup hedonis dengan perilaku konsumtif.

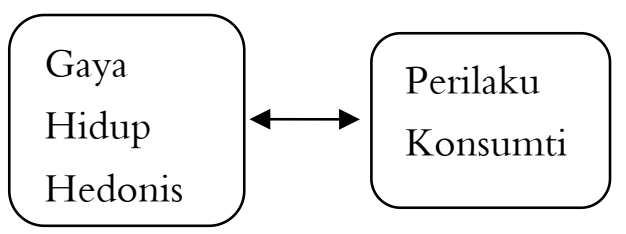

Gambar 1. Kerangka pemikiran penelitian

\section{Gaya Hidup Hedonis}

Menurut Solomon (dalam Nurvitria, 2015: 12) gaya hidup hedonis adalah perilaku atau kebiasaan seorang individu untuk menghabiskan waktunya hanya untuk bersenang-senang bersama teman sepermainan dan ingin menjadi pusat perhatian di lingkungannya. Selanjutnya, aspek-aspek dari gaya hidup hedonis dapat mengacu pada aspek-aspek gaya hidup menurut Mowen dan Minor (Sumarwan, 2002: 60 dan dalam Nurvitria, 2015: 35), yaitu: Pertama, Activity (aktivitas) merupakan cara orang mempergunakan waktu yang berwujud tindakan yang nyata yang dapat diamati seperti hobby, bercakap-cakap, belanja, berpergian, kegiatan sosial, hiburan, dan olahraga. Pengukuran ini ditunjukkan kepada alasanalasan mengapa melakukan aktivitas tersebut. Kedua, Interest (minat) adalah tingkat kesenangan yang timbul secara khusus dan membuat orang tersebut memperhatikan terhadap objek, peristiwa atau topik tertentu. Ketiga, Opinion (opini) atau pendapat adalah tanggapan atau respon seseorang secara lisan atau tulisan terhadap stimulus yang muncul. Stimulus atau situasi tersebut dapat berupa isu sosial, produk masa yang akan datang, komunitas, olahraga, atau hiburan.

\section{Perilaku Konsumtif}

Adapun Mowen dan Minor (dalam Effendi, 2016: 17) menyebutkan bahwa perilaku konsumtif didefinisikan sebagai studi unit pembelian dan proses pertukaran yang melibatkan perolehan, konsumsi, dan pembuangan barang, jasa, pengalaman, serta ide-ide. Aspek perilaku konsumtif menurut Lina dan Rasyid (dalam Fardhani \& Izzati, 2013), yaitu:

a. Aspek pembelian impulsif, yaitu aspek pembelian yang didasarkan pada dorongan dalam diri individu yang muncul tiba-tiba.

b. Aspek pembelian tidak rasional, yaitu aspek pembelian yang dilakukan bukan karena kebutuhan, tetapi karena gengsi agar dapat dikesankan sebagai orang yang modern atau mengikuti mode.

c. Aspek pembelian yang berlebihan, yaitu aspek pembelian suatu produk secara berlebihan yang dilakukan oleh konsumen.

\section{B. METODE}

Metode yang digunakan dalam penelitian ini adalah penelitian kuantitatif dengan jenis penelitiannya adalah penelitian korelasional, yaitu suatu jenis penelitian yang melihat hubungan antara satu atau beberapa ubahan dengan satu atau beberapa ubahan lain. Populasi pada penelitian ini adalah mahasiswi semester IV Prodi Pendidikan Dokter Universitas Baiturrahmah kota Padang berjumlah 108 orang dengan sampel sebanyak 84 orang. Teknik penarikan sampel yang digunakan adalah simple random sampling.

Metode pengumpulan data menggunakan skala psikologi dengan model modifikasi skala Likert yaitu skala gaya hidup hedonis dan skala perilaku konsumtif. Skala gaya hidup hedonis mengacu pada aspek gaya hidup yang dikemukakan oleh Mowen dan Minor yaitu Activity, Interest, dan Opinion. Selanjutnya, skala perilaku konsumtif mengacu pada aspek perilaku konsumtif yang dikemukakan oleh Lina dan Rasyid yaitu 
pembelian yang impulsif, pembelian tidak rasional, dan pembelian yang berlebihan. Koefisien reliabilitas masing-masing skala dengan menggunakan alpha Cronbach sebesar 0, 931 dan 0, 946. Teknik analisis data yang digunakan adalah analisis Pearson Correlation yaitu untuk mengetahui hubungan variabel bebas dan variabel terikat. Keseluruhan teknik analisis data menggunakan program SPSS 20.0 for windows.

\section{HASIL PENELITIAN}

Berikut ini beberapa hasil yang ditemukan, yaitu:

1 .

Kategorisasi Skor Gaya

Hidup Hedonis Mahasiswi Semester IV Program Studi Pendidikan Dokter

Tabel 1. Kategorisasi Skor Gaya Hidup Hedonis

\begin{tabular}{c|c|c|c|c}
\hline $\begin{array}{c}\text { N } \\
\text { o }\end{array}$ & Skor & $\begin{array}{c}\text { Jum } \\
\text { lah }\end{array}$ & $\begin{array}{c}\text { Katego } \\
\text { ri }\end{array}$ & $\begin{array}{c}\text { Persen- } \\
\text { tase }\end{array}$ \\
\hline 1 & $63-97$ & 38 & Rendah & $45 \%$ \\
2 & $\begin{array}{c}98- \\
130\end{array}$ & 46 & Tinggi & $55 \%$ \\
\hline
\end{tabular}

Berdasarkan tabel 1. di atas menunjukkan bahwa dari 84 subjek yang diteliti, 38 orang atau $45 \%$ memiliki tingkat gaya hidup hedonis yang rendah, 46 orang atau $55 \%$ yang memiliki tingkat gaya hidup hedonis yang tinggi. Persentase nilai kategorisasi gaya hidup hedonis lebih besar pada kategorisasi tinggi. Hal ini mengindikasikan bahwa mahasiswi semester IV Program Studi Pendidikan Dokter Universitas Baiturrahmah Padang sebagian besar memiliki tingkat gaya hidup hedonis yang dikategorikan tinggi.

2. Kategorisasi Skor Perilaku Konsumtif Mahasiswi Semester IV Program Studi Pendidikan Dokter
Tabel 2. Kategorisasi Skala Perilaku Konsumtif

\begin{tabular}{|c|c|c|c|c|}
\hline $\begin{array}{c}\mathbf{N} \\
\mathbf{0}\end{array}$ & Skor & $\begin{array}{c}\text { Jum } \\
\text { lah }\end{array}$ & $\begin{array}{l}\text { Kate } \\
\text { gori }\end{array}$ & $\begin{array}{l}\text { Perse } \\
\text { n-tase }\end{array}$ \\
\hline 1 & $\begin{array}{c}58- \\
96\end{array}$ & 35 & $\begin{array}{c}\text { Renda } \\
h\end{array}$ & $42 \%$ \\
\hline 2 & $\begin{array}{l}97- \\
133\end{array}$ & 49 & $\underset{\mathrm{i}}{\text { Tingg }}$ & $58 \%$ \\
\hline
\end{tabular}

Pada tabel 2. menunjukkan bahwa dari 84 subjek yang diteliti, 35 orang atau $42 \%$ memiliki tingkat perilaku konsumtif yang rendah, 49 orang atau $58 \%$ yang memiliki tingkat perilaku konsumtif yang tinggi. Persentase nilai kategorisasi perilaku konsumtif lebih besar pada kategorisasi tinggi. Hal ini mengindikasikan bahwa mahasiswi semester IV Program Studi Pendidikan Dokter Universitas Baiturrahmah Padang sebagian besar memiliki tingkat perilaku konsumtif yang dikategorikan tinggi.

3. Hubungan Gaya Hidup Hedonis dengan Perilaku Konsumtif

Berdasarkan hasil analisis data yang dilakukan maka diperoleh nilai koefisien pearson correlation gaya hidup hedonis dan perilaku konsumtif sebesar 0,497, dengan nilai signifikansi 0,000 . Hal ini menunjukkan bahwa jika nilai signifikansi $<0,05$ berarti hipotesis diterima, sehingga terdapat hubungan gaya hidup hedonis dengan perilaku konsumtif mahasiswi semester IV Program Studi Pendidikan Dokter Universitas Baiturrahmah kota Padang.

Sumbangan efektif variabel dalam penelitian ini diuji dengan menggunakan analisis regresi linier sederhana untuk mengetahui pengaruh gaya hidup hedonis terhadap perilaku konsumtif. Perhitungan analisis linier dengan menggunakan program SPSS 20.0 for windows memperoleh nilai R- square sebesar 0,247. Artinya adalah gaya hidup hedonis 
memberikan sebesar $24,7 \%$ terhadap perilaku konsumtif, sisanya 75,3 \% dipengaruhi oleh faktor lain.

\section{PEMBAHASAN}

Berdasarkan hasil penelitian yang telah diuraikan sebelumnya, maka dapat dibahas beberapa hal berikut ini.

1. Gaya hidup hedonis pada mahasiswi

Pada tabel 1. sebelumnya dapat dilihat bahwa subjek yaitu mahasiswi memiliki skor yang tinggi pada gaya hidup hedonis yaitu sebanyak 55\%. Seorang mahasiswi dikatakan memiliki gaya hidup hedonis yang tinggi ketika cenderung menjadikan kesenangan atau pemuasan dari keinginan-keinginannya sebagai tujuan dalam hidupnya. Mereka akan berusaha sebisa mungkin mencapai kesenangan dan kepuasan dalam dirinya. Semua itu dilakukan agar diakui di lingkungan sosialnya, berusaha memantaskan diri agar orang mengetahui bagaimana status sosialnya. Seperti yang dinyatakan oleh Susanto bahwa remaja yang memiliki kecenderungan gaya hidup hedonis biasanya akan berusaha agar sesuai dengan status sosial hedon, melalui gaya hidup yang tercermin dengan simbol-simbol tertentu, seperti merekmerek yang digunakan dalam kehidupan sehari-hari, dan segala sesuatu yang berhubungan serta dapat menunjukkan tingkat status sosial yang tinggi. Tujuan mahasiswa mengikuti trend ialah supaya diterima oleh lingkungan bergaulnya, terutama di kalangan remaja pemerhati tren juga (Kresdianto, 2014).

Gaya hidup tersebut berpatokan pada style yang diciptakan dari orang lain atau melalui media. Misalnya menggunakan pakaian yang sesuai dengan model terkini. Eksistensi kaum muda dihargai hanya sebatas kepemilikan dan status semata. Keinginan memiliki benda-benda khususnya pakaian yang sesuai mode dikalangan mahasiswa hanya sebatas pengakuan pada status sosial kelas atas dan pengakuan dari mahasiswa lain akan status sosialnya (Arbaini, 2017).

2. Perilaku konsumtif pada mahasiswi

Pada penelitian ini ditemukan, subjek memiliki skor yang tinggi pada perilaku konsumtif sebesar $58 \%$. Seorang mahasiswi dikatakan memiliki perilaku konsumtif yang tinggi ketika mereka cenderung tidak mempertimbangkan terlebih dahulu sebelum mengeluarkan uangnya untuk mendapatkan sesuatu. Kurangnya kontrol di dalam diri sehingga membeli sesuatu secara berlebihan di luar batas kebutuhan rasionalnya. Membeli hanya karena untuk pemenuhan keinginannya saja, tanpa diketahui adanya kebutuhan yang jelas, bahkan terkadang memang tidak dibutuhkan.

Sesuai dengan yang dinyatakan oleh Parma (dalam Artaningtyas, 2015) bahwa perilaku konsumtif pada remaja putri adalah tindakan yang terlihat secara nyata dalam mendapatkan, mengkonsumsi (menggunakan) dan menghabiskan barang hasil industri dan jasa tanpa batas dan lepas kendali yang ditandai dengan kehidupan mewah dan berlebihan. Begitupun dengan pendapat Kotler (dalam Chrisnawati \& Abdullah, 2011) bahwa perilaku konsumtif merupakan suatu tindakan untuk mengkonsumsi produk karena adanya perasaan ingin memiliki sesuatu benda yang berupa barang atau jasa, namun bukan berdasar kebutuhan akan tetapi karena keinginan untuk menggunakan atau membeli sesuatu dengan hanya memenuhi hasrat kesenangan semata tanpa dapat membedakan antara kebutuhan, keinginan ataupun permintaan.

3. Hubungan gaya hidup hedonis dengan perilaku konsumtif mahasiswi 
Hasil penelitian ini menunjukkan terdapat hubungan daya hidup hedonis dengan perilaku konsumtif mahasiswi. Hal tersebut sejalan dengan teori yang dikemukakan oleh Hawkins (dalam Hariyono, 2015) bahwa gaya hidup merupakan salah satu faktor yang mempengaruhi perilaku konsumtif, karena gaya hidup seseorang mempengaruhi kebutuhan, keinginan, serta perilakunya termasuk perilaku membeli. Hawkins juga mengatakan gaya hidup juga seringkali dijadikan motivasi dasar dan pedoman dalam membeli sesuatu. Ini berarti, individu dalam membeli suatu produk mengacu pada gaya hidup yang dianutnya. peranan dalam perilaku membeli mereka.

Penelitian ini juga sesuai dengan penelitian terdahulu yaitu penelitian yang dilakukan oleh Kresdianto (2014) yang berjudul "Hubungan Gaya Hidup Hedonis dengan Perilaku Konsumtif Fashion Pakaian Pada Mahasiswi Di Fakultas Psikologi UIN Maliki Malang”. Hasil penelitiannya menunjukkan bahwa gaya hidup hedonis memberikan sumbangan efektif yang lebih besar terhadap perilaku konsumtif dibangdingkan faktor lain. Selanjutnya penelitian ini juga sesuai dengan penelitian lain yaitu penelitian yang dilakukan oleh Alwer (2017) yang berjudul "Hubungan antara Gaya Hidup Hedonis dengan Perilaku Konsumtif Fashion pada Mahasiswi Universitas Mercu Buana Yogyakarta”. Penelitian ini juga menunjukkan bahwa gaya hidup hedonis memberikan sumbangan efektif yang lebih besar terhadap perilaku kosnumtif dibangkan faktor lainnya.

Hal yang berbeda antara penelitian ini dengan penelitian terdahulu yaitu penelitian terdahulu memfokuskan perilaku konsumtif pada fashion saja sedangkan penelitian ini mencakup perilaku konsumtif secara keseluruhan, misalnya pada makanan, kosmetik, aksesoris, dan sebagainya. Kemudian penelitian terdahulu menunjukkan sumbangan efektif yang lebih besar oleh gaya hidup hedonis terhadap perilaku konsumtif dibandingkan faktor lain, sedangkan pada penelitian ini diperoleh sumbangan efektif sebesar yang rendah.

Salah satu penyebab adanya perbedaan tinggi rendahnya sumbangan efektif yang diberikan mungkin adalah karena faktor demografi yaitu wilayah geografis atau wilayah tempat tinggal. Penelitian terdahulu dilakukan di kotakota besar yang lebih maju dibanding kota tempat penelitian oleh peneliti. Keadaan tempat penelitian menjadi berpengaruh terhadap besar kecilnya sumbangan efektif yang diberikan. Sesuai dengan yang dikatakan oleh Intisari (dalam Purwaningsih, 2008: 10) bahwa banyak faktor yang mempengaruhi pemilihan sebuah gaya hidup, diantaranya adalah latar belakang budaya, agama, pendidikan, lingkungan sosial, tingkat kesejahteraan, sarana dan prasarana, atau wilayah tempat tinggal. Sejalan juga dengan pendapat Gidden (dalam Arbaini, 2017) yang mengatakan bahwa gaya hidup dipengaruhi oleh aspek kebudayaan, demografi, ekonomi dan aspek psikologi yang ada pada individu.

\section{E. SIMPULAN DAN SARAN}

Berdasarkan hasil penelitian yang diuraikan maka dapat diperoleh kesimpulan bahwa mahasiswi semester IV Program Studi Pendidikan Dokter Universitas Baiturrahmah Padang memiliki gaya hidup hedonis dan perilaku konsumtif yang tinggi. Selanjutnya, terdapat hubungan gaya hidup hedonis dengan perilaku konsumtif pada mahasiswi semester IV Program Studi Pendidikan Dokter Universitas Baiturrahmah Padang. 
Sehingga semakin tinggi tingkat gaya hidup hedonis pada mahasiswi maka semakin tinggi pula perilaku konsumtifnya. Sebaliknya, semakin rendah tingkat gaya hidup hedonis pada mahasiswi maka semakin rendah pula perilaku konsumtifnya.

Berdasarkan hasil penelitian yang telah dilakukan, maka peneliti memberikan saran yang dapat dijadikan sebagai pertimbangan dan diharapkan dapat bermanfaat, di antaranya:

1. Bagi Subjek atau Mahasiswi Lainnya

Bagi mahasiswi agar dapat lebih menunjukkan sikap atau gaya hidup yang sederhana dan memiliki kontrol diri yang kuat. Agar lebih bisa memanfaatkan uang yang ada atau dimiliki untuk hal atau benda yang lebih bermanfaat atau memang dibutuhkan. Tidak masalah jika membeli sesuatu yang diinginkan, tetapi jangan sampai juga melebihi batas rasionalnya.

2. Bagi Peneliti Selanjutnya

$$
\text { Bagi peneliti selanjutnya, }
$$
disarankan untuk melakukan penelusuran sumber dan literatur yang lebih banyak, guna untuk memperkaya terhadap teori-teori yang mendukung dan diharapkan lebih memperhatikan faktor-faktor lain yang berhubungan dengan tingkat gaya hidup hedonis dan perilaku perilaku konsumtif, seperti keadaan ekonomi, kebudayaan, persepsi, dan lain-lain.

\section{DAFTAR KEPUSTAKAAN}

Alwer, M. N. (2017). Hubungan antara Gaya Hidup Hedonis dengan Perilaku Konsumtif Fashion pada Mahasiswi Universitas Mercu Buana Yogyakarta. Skripsi (dipublikasikan). Yogyakarta: Fakultas Psikologi Universitas Mercu Buana Yogyakarta.
Arbaini, N. (2017). Gaya Hidup Shopaholic pada Mahasiswa (Studi pada Mahasiswa FISIP Universitas Riau yang Kecanduan Berbelanja Pakaian). Jom FISIP, 4(1), 1-11.

Artaningtyas, R. M. (2015). Hubungan antara Konsep Diri dengan Perilaku Konsumtif pada Mahasiswa Universitas Muhammadiyah Surakarta. Naskah Publikasi (dipublikasikan). Surakarta: Fakultas Psikologi Universitas Muhammadiyah Surakarta.

Chrisnawati, D., \& Abdullah, S. M. (2011). Faktor-Faktor yang Mempengaruhi Perilaku Konsumtif Remaja terhadap Pakaian (Studi Kasus Pada Remaja Berstatus Sosial Ekonomi Rendah). Jurnal Spirits, 2(1), 1-14

Ermawati, E., \& Indriyati, E. P. (2011). Hubungan antara Konsep Diri dengan Perilaku Konsumtif pada Remaja di SMP N 1 Piyungan. Jurnal Spirits, 2(1), 1-12.

Fitriani, \& Romas, M. Z. (2014). Hubungan Konsep Diri dengan Perilaku Konsumtif Pada Remaja di SMK Kesehatan.pdf. Jurnal Psikologi, 10, 1-11

Halim, DK. (2008). Psikologi Lingkungan Perkotaan. Jakarta: Bumi Aksara.

Hariyono, P. (2015). Hubungan Gaya Hidup Dan Konformitas Dengan Perilaku Konsumtif Pada Remaja Siswa Sekolah Menengah Atas Negeri 5 Samarinda. eJournal Psikologi, 3(2), 569-578.

Hasibuan, E.P.N. (2010). Hubungan antara Gaya Hidup Brand Minded dengan Kecendrungan Perilaku konsumtif 
pada Remaja Puteri. Skripsi (dipublikasikan). Medan: Fakultas Psikologi Universitas Sumatera Utara.

Kresdianto, D. (2014). Hubungan Gaya Hidup Hedonis dengan Perilaku Konsumtif Fashion Pakaian pada Mahasiswi di Fakultas Psikologi UIN Maliki Malang. Skripsi (dipublikasikan). Malang: Fakultas Psikologi UIN Maulana Malik Ibrahim Malang.

Mar'at, S. (2012). Psikologi Perkembangan. Bandung: PT Remaja Rosdakarya.

Mufidah, N. L. (2012). Pola Konsumsi Masyarakat Perkotaan: Studi Deskriptif Pemanfaatan Foodcourt oleh Keluarga. BioKultur, 1(2), 157178.

Murbani, B. (2010). Hubungan antara Kepercayaan Diri dengan perilaku Konsumtif pada Remaja. Skripsi (dipublikasikan). Yogyakarta: Fakultas Psikologi Universitas Sanata Dharma Yogyakarta.

Ningsih, R. A. A.S., \& Bawono, Y. (2016). Hubungan Antara Perilaku Konsumtif Pada Produk X Dengan Citra Diri Remaja Putri. Jurnal Mediapsi, 2(1), 45-50.

Purwaningsih, M. F. (2008). Analisis Hubungan Gaya Hidup dan Pendapatan dengan Keputusan Pembelian Produk Fashion Planet Surf. Skripsi (dipublikasikan). Yogyakarta: Fakultas Psikologi Universitas Sanata Dharma Yogyakarta.

Wahidah, N. (2013). Pengaruh Perilaku Konsumtif terhadap Gaya Hidup
Mahasiswa Pendidikan Ekonomi FKIP UNTAN. Artikel Penelitian (dipublikasikan). Pontianak: Fakultas Keguruan dan Ilmu Pendidikan Universitas Tanjungpura. 